\title{
Reviews and Expectations on the Maiden Voyage of a Chinese Merchant Ship in the Arctic Northeast Route
}

\author{
Liu Jia-zhao, Liu Xiao-pei and Zhang Xiao \\ Qingdao Ocean Shipping Mariners Collage, Qingdao 266071, People's Republic of China
}

\begin{abstract}
This paper introduces the preparatory work and conducts an integrated review on the maiden voyage of a Chinese commercial ship on the Arctic Northeast Route. It puts forth expectations on the exploitation and utilization of the Arctic Northeast Route in the aspects of safety, fastness, low costs, low consumption of energy and less pollution, knowledge of maritime law and navigation practice, building seaworthiness ships and making studies on the methods of sailing and maneuvering for navigation in polar waters, training qualified seafarers with navigation experiences in ice waters and establishing a safeguard system for the navigation in this route through the analysis on the weather, temperature, ice condition, route and hydrology encountered in the practice of a Chinese merchant ship in its maiden voyage in the route, and studies on the ice pilotage, convoy by icebreaker, practical condition of communication and navigation equipment in sea areas of high latitude and the economic benefit of the navigation in the Arctic Northeast Route.
\end{abstract}

Key words: The Arctic Northeast Route, Northern Sea Route, NSR, Navigation in Polar Area.

With the continuing of global warming, the melting of the ice and snow in the Arctic Ocean is faster than expectations. By the middle of this century, there will possibly be no ice in summer in the Arctic Ocean. The opening of the Arctic route will not be a dream and shipping companies are putting their eyes on this future golden route.

With the support and assistance of the state departments, COSCO (China Ocean Shipping (Group) Company) decided to implement the "Seapard Project," the trial operation in sailing in the Arctic Northeast Route to take the lead in the research and practice in opening the Middle-Northwestern European route that is safer, lower cost, lower energy consumption and less pollution.

\section{Review on the Maiden Voyage of a Chinese Merchant Ship in the Arctic Northeast Route}

\subsection{The Arctic Northeast Route and Russian North Sea Routes}

Between the two Arctic routes that have been

Corresponding author: Liu Xiao-pei, professor, research fields: engaged in the study and teaching of linguistics and maritime English. opened, one is the "Northeast Route" whose most part is located in Russian North Sea, and the other is the "Northwest Route" which is located in the Arctic island areas of Canada. Integrating all the considerations concerned, COSCO selected the "Northeast Route" as the one for its maiden voyage in sailing across the Arctic Pole.

The Arctic Northeast Route refers to the one that goes through the Arctic waters, starting from Bering Strait, along Russian North Sea, through Barents Sea and reaches North Europe. The NSR (Northern Sea Route) is the main route in the Arctic Northeast Route, strating from the north of Bering Strait, passing through Chukchi Sea, East Siberian Sea, New Siberian Islands, Severnaya Zemlya, Kara Sea and reaches the north of Novaya Zemlya.

\subsection{Preparatory Work of the "Seapard Project"}

\subsubsection{Selection of the Maiden Ship}

The original plan of the "Seapard Project" was to send two ships to form a fleet through the Arctic Northeast Route, but in accordance with the ice information released by Northern Sea Route Administration on its website, there was middle class 
ice in East Siberian Sea areas June to August in 2013. In accordance with the "Regulations for Navigation on the Seaways of the Northern Sea Route" of Russia, in case there is ice of middle class in Chukchi Sea, East Siberian Sea and Laptev Sea, ships without ice strengthening are forbidden, not even those having acquired the transit permit and convoyed with icebreakers. After considerations, COSCO decided to arrange the single ship MV "Yong Sheng" with B1 ice class to complete the commission of "Seapard Project" in the maiden voyage of a Chinese merchant ship to navigate the Arctic Pole on the Northeast Route.

MV "Yong Sheng", built in 2002, a multi purpose dry cargo carrier; 159.95 meters in length, 23.70 meters in width, 11.95 meters in molded depth and 8.599 meters in summer draft; $1 \mathrm{~A}$ ice class of Finn and Sweden standards (= CCS Ice Class B1), 14,357 GT and 19,561 dwt, with the MAN B \& W 6 S40C-C main engine of 7,860 KW and a service speed of 14 knots.

\subsubsection{Selection and Training of Seafarers}

In accordance with the IMO "Guidelines for Ships Operating in Polar Waters" and "Russian Federal Law of Shipping on the Water Area of the Northern Sea Route", seafarers on ships sailing in polar waters or those transiting the ice-covered Russian territorial waters shall have received special training and acquired the training certificates issued by the maritime administrations of the flag states. To satisfy the requirements, COSCO Shipping has selected seafarers to participate in the special training for sailing in polar waters and chose from the trainees 15 seafarers familiar with MV "Yong Sheng" and had serviced onboard the ship to take part in the "Seapard Project." China MSA issued the "Certificate of Trainings for Seafarers Navigating in Arctic Waters of the People's Republic of China" for the 15 seafarers.

1.2.3 Acquisition of the Navigation Permit

In accordance with the "Russian Federal Law of Shipping on the Water Area of the Northern Sea
Route", ships transiting in NSR shall acquire the navigation permit from Russia. For this, COSCO Shipping applied for the "Navigation Permit for Ships Sailing in Northern Sea Route" through the website of Northern Sea Route Administration and acquired the Permit July 1st for consent of MV "Yong Sheng" to transit NSR August to September, 2013.

\subsubsection{Voyage Risk Assessment}

For the success of the "Seapard Project" in the trial operation in Arctic Northeast Route, MV "Yong Sheng" conducted overall assessment on the risks of the navigation, with the contents including:

(1) Seaworthiness of the ship (including prevention against ice);

(2) Ship stability, maximum draft, trim, ship strength and its influence on the safe shipping prior to departure;

(3) Stand-by condition of the emergency equipment;

(4) State of the special equipment specially required for the ships sailing in the ice-covered Russian territorial waters;

(5) Risk of failure of main and auxiliary engines, steering and anchor gears and boiler;

(6) Condition of communication and navigation equipment in high latitude sea areas;

(7) Preparations of the necessary pollution prevention and plugging equipment;

(8) Considerations on the use of ballast tanks;

(9) Location of emergency power (generators) and whether to take measures to prevent freezing and shift;

(10) Considerations on the storage of ship pollutants (tanks) and capacity;

(11) Considerations on the insulation of the deck equipment;

(12) Safe storage of fuel oil and fresh water, etc;

(13) Species and amount of foods;

(14) Readiness and updating of navigational publications;

(15) Correctness and updating of chart scales;

(16) Reliability of the chart materials; 
(17) Risks analysis on 5 sea areas and 4 straits the ship will transit in Arctic Northeast Route;

(18) General assessments on navigation risks, environmental protection risks, security risks, geopolitics risks and legal risks of the sea areas of "Seapard Project";

(19) Preparation of the standby ports of shelter (anchorages) and the corresponding charts and navigational publications;

(20) Cargo carriage and stowage and securing plans;

(21) Risks of cargo accidents, pollution and shift;

(22) Overall and segmental assessment of the transiting environments;

(23) Health and mental readiness of seafarers in the maiden voyage, familiarization with emergency knowledge on polar navigation, assessment on the operation and familiarization with the emergency equipment and facilities for sailing in polar waters;

(24) Readiness of the various necessary ship and seafarer certificates;

(25) Readiness of the "Operational manual" and "Training manual" required by the Russian Government;

(26) Necessary facilitation of the muster list and emergency response procedures;

(27) Special arrangement of navigational duty in ice areas and poor visibility;

(28) Whether emergency plan has been made for evacuation to ice in accordance with the characteristics of navigation in ice, etc.

1.2.5 Installation of Communication Equipment Applicable to Navigation in High Latitude

On account that the maiden voyage of MV "Yong Sheng" in Arctic Northeast Route included navigation in A4 areas and high latitude, the communication equipment applicable to navigation in high latitude was installed on the ship prior to navigation, including middle and high frequency component station (NBDP) applicable to A4 areas, IRDM telephone applicable to high latitude sea areas (to the north of $75^{\circ} \mathrm{N}$ ), GPS compasses for error correction in high latitude (to the north of $\left.75^{\circ} \mathrm{N}\right), 122.5 \mathrm{MHz}$ air high frequency telephone used for the communication between the ship in polar waters and airplanes or helicopters and ANSCHUTZ gyrocompasses corrected for high latitude, etc.

1.2.6 Provision of the Navigation Publications Necessary for Transiting the Arctic Northeast Route

To complete the "Seapard Project," COSCO Shipping purchased 8 British Admiralty Charts from Bering Strait to the North Point of Norway for MV "Yong Sheng" and purchased 49 Russian charts via Moscow office of COSCO and equipped MV "Yong Sheng" with the British Notices to Mariners (NP10) and other publications necessary for transiting the Arctic Northeast Route.

1.2.7 Provision of the Equipment Necessary for Transiting the Arctic Northeast Route

In accordance with the "Requirement for the Design, Equipment and Supplies of Vessel Navigating the Northern Sea Route" of Russia and the "Regulations for Navigation on the Seaways of the Northern Sea Route," in addition to the installation of the communication and navigation equipment that would satisfy the requirements for sailing in A4 areas, COSCO has provided the seafarers' cold and protective equipment necessary for transiting NSR, ice hammers and pickles, hand-held welding equipment, 100 tons per hour immersible pumps, manual start red flash lights visible at the stern and plugging equipment, etc. Purchase plans were also made before departure for PSK (personal survival kits) and GSK (group survival kits) unavailable in China.

1.2.8 Inspection on the Ship Equipment and Facilities Specially Required for Transiting the Arctic Northeast Route

In accordance with the requirements of "Guidelines for Ships Operating in Polar Waters" and "Guide to navigating through the Northern Sea Route," earnest and careful inspections were made on the equipment and facilities specially required of the emergency 
steering gear, emergency towing devices, emergency generators, emergency fire pumps, sludge tanks, bilge water tanks, stern tube bearing oil seals of the tail shafts, life boats and rafts, pollution prevention equipment, searchlights $(2,000 \mathrm{~W})$ and ice melting devices on the bridge windows of MV "Yong Sheng", etc. to ensure that the equipment and facilities meet the requirements of the guidelines and directions.

1.2.9 Compilation of the Operational and Training Manuals

In accordance with the "Polar Code," all ships sailing in the polar waters shall carry onboard the ship operational and training manuals applicable to those sailing in polar areas. COSCO Shipping invited the relevant organizations and institutions to compile the "Operational manual for ships sailing in the Arctic Pole" and "Training manual for seafarers on ships sailing in the Arctic Pole" in English and Chinese versions and had them printed and distributed to ships.

\subsubsection{Making of the Voyage Plan}

For its maiden voyage, MV "Yong Sheng" was to sail in brand new and complicated polar areas. To ensure the safety of navigation, prior to the departure, the shipping departments of COSCO Shipping assisted the ship to draft two voyage plans for transiting the Arctic Northeast Route and organized the experts to conduct the risk assessment on the plans and made corresponding marks on the dangerous objects and shallow waters on the charts.

1.2.11 Making of the Safety Measures to Ensure the Safety of Navigation

MV "Yong Sheng" was to face with the adverse conditions of low temperature, freezing, severe natural conditions, limits in communication, errors in navigation aids, weakness of search and rescue, higher requirements on ocean environmental protection and sensitiveness of geopolitics, etc in its maiden voyage transiting the polar waters. For these, COSCO Shipping made a series of procedures to ensure the normal working conditions for communication and navigation equipment in polar waters, measures to ensure the stability in satisfaction of the safe navigation requirements for sailing in polar waters, methods for the collection of meteorological and ice information, plans for reporting the normal information, main points for safe operation in transiting the sea areas in the Arctic Northeast Route, essentials for safe maneuvering under pilotage and convoy of icebreakers and precautions for masters, etc.

1.2.12 Making of Contingency Plans and Operational Instructions

On basis of the existing SMS documents, COSCO Shipping made 18 contingency plans and operational instructions for the "Seapard Project," including, Operational instructions for land base emergency reaction; Operational instructions for ships sailing in ice areas; Operational instructions for anti-freezing of ships; Operational instructions for ship emergency communication; Operational instructions for disposal of flooding in hull; Operational instructions for emergency disposal of oil spill pollution; Operational instructions for ship emergency towing and Operational instructions for helicopter rescue, etc. In addition, COSCO Shipping distributed onboard the contact means for search and rescue in Arctic waters announced by IMO and the contact means for search and rescue in Northern Sea areas announced by Russia, as parts of the contingency plan of the ship.

\subsubsection{Emergency Drills}

In accordance with the possible situations of floating ice, collision on icebergs, causing damage to the hull, flooding and oil leakage, etc., that the ship might encounter in the Arctic Northeast Route, MV "Yong Sheng" conducted a series of emergency drills prior to entering the route, including fire prevention, ship abandoning, oil pollution, emergency rudder operation and plugging.

\subsection{Conclusion of the "Seapard Project"}

1.3.1 Weather Situation

August 27th to 28th, MV "Yong Sheng" was 
transiting Chukchi Sea, and the area was under the effect of low pressure, with the pressure of 1,001 mpa and northeast wind of 4 degree, cloudy. August 28th, the ship entered the high pressure area and the wind turned to north, with 4 to 5 highest degree, fine and good visibility. August 20th to 30th, "Yong Sheng" sailed through the Eastern Siberian Sea and the area was under control of high pressure, between 1,012 to 1,023 mpa, and the wind turned to north and northwest, 2 to 3 degrees, fine and good visibility. August 30th, the ship sailed to low pressure areas and the wind turned to south and southwest, with short intervals of 6 degree southwest winds, fine but poor visibility on account of the differences of temperature. August 31st to September 1st, "Yong Sheng" was transiting the Laptev Sea, under the control of low pressure, changing winds, 3 to 4 degrees, with intervals of 7 degrees, cloudy and good visibility. September 1st to 3rd, "Yong Sheng" transited the Kara Sea, under the control of low pressure, changing winds, 2 to 3 degrees, cloudy and rainy, poor visibility. September 3rd to 6th, "Yong Sheng" sailed through the Barents Sea, under the control of low pressure, with mostly north winds, 5 degree of power, cloudy and rainy, but good visibility.

The maximum wind power that MV "Yong Sheng" encountered when sailing in the Arctic Northeast Route was in the Laptev Sea areas September 1st, with west wind and 7 degree, but lasting only 1 hour.

\subsubsection{Air and Water Temperatures}

Table 1 shows the air and water temperatures of the sea areas when MV "Yong Sheng" was sailing in the Arctic Northeast Route. The lowest temperature that "Yong Sheng" encountered when transiting the Arctic
Northeast Route was in Eastern Siberian Sea, $-5{ }^{\circ} \mathrm{C}$, but basically there was not freezing on the deck of the ship.

\subsubsection{Ice Conditions}

When sailing in NSR, MV "Yong Sheng" did not encounter any ice in Chukchi Sea and Barents Sea and there was floating ice in Eastern Siberian Sea, Vilkitskogo Strait and Kara Sea. The sea ice density in Eastern Siberian Sea was between 2/10 and 3/10, adult ice, 0.3 meters thick, with little influence on the navigation of MV "Yong Sheng." At the entrance of Vilkitskogo Strait, the sea ice density was below 2/10, current year ice, 0.2 to 0.5 meters in thickness. The sea ice density in Vilkitskogo Strait was between $2 / 10 \sim 3 / 10$ while it was between $5 / 10 \sim 6 / 10$ in the west, mainly the current year ice, with a thickness of 0.2 to 0.5 meters. The sea ice density in the south of Severnaya Zemlya and east of Kara Sea was 6/10 $9 / 10$, a mixture of adult and current year ice, with a thickness of 0.5 to 1.3 meters. Around Kirov Island, the sea ice density was $6 / 10$, mostly multi year ice, with a thickness of 0.2 to 0.4 meters. MV "Yong Sheng" encountered the severe ice conditions in Kara Sea, with the sea ice density of 6 9 and the ship had to follow closely the icebreaker and sail in the water channel opened, otherwise the channel would be jammed with broken ice and the ship would lose its safe channel in navigation through ice.

1.3.4 Weather Forecast and Ice Information

Considering that it was hardly possible to receive any local weather forecast and ice information for MV "Yong Sheng" when sailing in the Arctic Northeast Route, prior to departure, COSCO Group signed the agreement with the National Marine Environment

Table 1 Air and water temperatures of the sea areas when "Yong Sheng" was sailing in the Arctic Northeast Route.

\begin{tabular}{lll}
\hline Sea areas & Air temperature & Water temperature \\
\hline Chukchi Sea & $0{ }^{\circ} \mathrm{C} \sim 7{ }^{\circ} \mathrm{C}$ & $0{ }^{\circ} \mathrm{C} \sim 7{ }^{\circ} \mathrm{C}$ \\
Eastern Siberian Sea & $-5{ }^{\circ} \mathrm{C} \sim 1{ }^{\circ} \mathrm{C}$ & $-2{ }^{\circ} \mathrm{C} \sim 2{ }^{\circ} \mathrm{C}$ \\
Laptev Sea & $2{ }^{\circ} \mathrm{C} \sim 3.5^{\circ} \mathrm{C}$ & $-1.5{ }^{\circ} \mathrm{C} \sim 2{ }^{\circ} \mathrm{C}$ \\
Kara Sea & $1.5{ }^{\circ} \mathrm{C} \sim 7{ }^{\circ} \mathrm{C}$ & $-2.5^{\circ} \mathrm{C} \sim 6{ }^{\circ} \mathrm{C}$ \\
Barents Sea & $4{ }^{\circ} \mathrm{C} \sim 7{ }^{\circ} \mathrm{C}$ & $6.5^{\circ} \mathrm{C} \sim 7.5^{\circ} \mathrm{C}$ \\
\hline
\end{tabular}


Forecast Center for providing weather forecast, ice information and meteorological data through analysis. In the meantime, COSCO Shipping applied to the WNI Company for the meteorological and navigational service in the period when "Yong Sheng" was sailing in the NSR. On the field observation of "Yong Sheng," the weather forecast, ice information and meteorological and navigational data provided by the National Marine Environment Forecast Center and WNI Company were detailed and reliable, and except for the differences between the forecasted value and practical situation caused the directions of the floating ice, other weather forecast and ice information were basically identical with the practical observation, which had provided satisfactory technical assistance and supported for the safe navigation of the ship.

\subsubsection{Route and Hydrological Data}

In accordance with the introduction of the data, the situations in the Arctic Northeast Route and hydrological conditions were complicated in that, there are floating ice, icebergs and ice hills along the route and their natural characteristics are difficult to distinguish by vision and radar observation; large amounts of tiny islands and reefs are not marked or incorrectly marked on the charts; in radar images, the islands are easily mistaken for floating ice and icebergs; the measurements of routes and hydrological data are inadequate and lots of sea areas have not been measured accurately, etc. In the process in which "Yong Sheng" was transiting the Arctic Northeast Route, the description of the islands, straits and land shape of the Admiralty "Notices to Mariners (NP 10)" and the chart information provided by Russia was verified in accordance with the practical situation and it was found that the two were basically identical. When MV "Yong Sheng" entered the Arctic Northeast Route, the depth finders were kept running and the checks were made along the whole route, and the result shows that the depths measured along the route were identical with the marks on Russian charts. Therefore, it can be concluded that, the information of water depths on Russian charts is reliable.

\subsubsection{Pilotage in Ice Areas}

In accordance with the "Regulations for Navigation on the Seaways of the Northern Sea Route ", masters on ships sailing in NSR shall have a sea service experience for at least 3 months and more, and otherwise, the ships shall apply for pilotage in the ice areas of Russia. NSR pilotage may seem non-mandatory, but self-pilotage is very much limited and difficult. Russia has several pilotage companies certified by Northern Sea Management bureau for providing piloting service, with a cost of 2,000 US dollars per day. The time of pilotage for MV "Yong Sheng" in NSR was 119 hours, with a cost of 10 thousand dollars. What is necessary to point out is, the embarkation and disembarkation (the Port of Provideniya and outside Port of Murmansk) of the pilots as regulated by "Regulations for Navigation on the Seaways of the Northern Sea Route " are normally different from the actual places, depending on the ice conditions and the places of joining of the icebreaker and the ship under convey. The pilots are usually taken and sent by the icebreaker and many of them are deck officers of the icebreakers having acquired the NSR pilotage certificates.

\subsubsection{Convoy by the Icebreakers in the Ice Areas}

In accordance with the "Regulations for Navigation on the Seaways of the Northern Sea Route," when Chukchi Sea, Eastern Siberian Sea and Laptev Sea are covered with middle class ice, MV "Yong Sheng" of Class B1 can transit the areas independently, without the necessary convey of the icebreakers. However, on account of the lack of knowledge of the ice conditions in the Arctic Northeast Routes and in considering the possible unidentified factors and risks the ship might encounter when transiting the areas, in order to ensure the successful completion of the "Seapard Project," COSCO Shipping hired the icebreaking service from the Atomic Icebreaking and Pilotage Company of Russia, which sent the newest nuclear power icebreaker "50 LET POBEDY." "Yong Sheng" met 
the "50 LET POBEDY" at the joint of Chukchi Sea and Eastern Siberian Sea. Under the icebreaking, convoy and guidance, MV "Yong Sheng" sailed to the west of the ice area of Kara Sea, with a total icebreaking and convoy time of 127 hours and 35 minutes. The total cost was 160 thousand dollars.

1.3.8 The Use of Communication and Navigation Equipment in High Latitude

The use of communication and navigation equipment on MV "Yong Sheng" in the transit through the Arctic Northeast Route is as follows. The maritime satellite communication equipment was in normal state in the sea areas to the south of $77^{\circ} \mathrm{N}$, but abnormal to the north. The ANSCHUTZ gyrocompass was in normal state in the sea areas to the south of $75.5^{\circ} \mathrm{N}$, but with a deviation ranging $2^{\circ} \sim 5^{\circ}$ between $75.5^{\circ} \mathrm{N} \sim 78.0^{\circ} \mathrm{N}$ (the highest latitude in this voyage). The magnetic compass had a large deviation when the ship entered the north of $75.5^{\circ} \mathrm{N}$ and the deviation was still moderate when the ship entered the areas to the south of $75.5^{\circ} \mathrm{N}$, which might be under the effect of "magnetic storm." There were no abnormal phenomena in the use of the communication equipment of GPS-gyro, ECDIS, AIS, GPS, Radar and radio component station, etc., in the sea areas of high latitude.

\subsubsection{Safety Inspection for Ships Sailing in NSR}

Russia would not conduct safety inspections for ships sailing in NSR after 2013, which was proved in the implementation of the "Seapard Project."

1.3.10 Environmental Protection in Polar Waters

Although MARPOL does not see the North Pole waters as special areas and ships can follow the pollution prevention rules other than those for special areas, yet COSCO Group required that "Yong Sheng" took measures when transiting the Arctic Northeast Route to minimize the pollution to the sea environment and atmosphere from the ship to make its maiden voyage a "green navigation" in the Arctic Northeast Route. For this, COSCO Shipping formulated detailed pollution prevention plans and measures for MV "Yong Sheng" and achieved "zero discharging" in transiting the Arctic Northeast Route.

1.3.11 Evaluation on the Economic Effect in the Use of the Arctic Northeast Route

MV "Yong Sheng" started its sail from the Port of Taicang of Jiangsu Province of China, through the Arctic Northeast Route and arrived in the Port of Rotterdam, with a total distance of 7,931 nautical miles, while the traditional voyage from Taicang to Rotterdam via Suez Canal is 10,711 nautical miles, with the former reducing the distance by 2,780 nautical miles, saving a voyage by 9.12 days counted by a speed of 12.7 knots of "Yong Sheng." The daily consumption of fuel oil of "Yong Sheng" is 28 tons and the voyage can save 252 tons counting by 9 days and reduce a cost of 150 thousand dollars counting by 600 dollars per ton. The expenditures of pilotage and icebreaking service of "Yong Sheng" are similar to that of transit cost through Suez Canal and antipiracy and security.

\section{Expectations and Suggestions on Developing and Exploiting the Arctic Northeast Route for Commercial Purposes}

The maiden voyage to North Pole waters is an active research and practice for the implementation of the strategy "strengthening the country by maritime transportation." The success of the "Seapard Project" reveals the feasibility for Chinese shipping industries to lay out the commercial transportation from China to northwest Europe via the Arctic Northeast Route and is a valuable demonstration for Chinese shipping industries to open up new commercial routes. Is the "Seapard Project" duplicable? What other problems and challenges are facing the commercial transportation via the Arctic Northeast Route? What new actions will be taken for Chinese shipping industries to further develop and exploit the Arctic Northeast Route for commercial transportation? We shall take a look into these questions. 


\subsection{Difficulties and Challenges}

The immense commercial value of the Arctic Northeast Route is beyond doubt, but there exist problems and challenges in the use of it in commercial transportation.

2.1.1 Uncertainty of the Applicable Laws and Legislations in Transiting NSR

The whole route is within the economic zone of Russia. The fact of whether NSR is an international navigable route and whether ships can render "harmless transit" through NSR causes controversy and disagreement between Russia and other countries, which will result in uncertainty and complicatedness in the application of laws and implementation of jurisdiction over ships transiting NSR.

\subsubsection{Influence of Geopolitics}

The NSR is within the Arctic Circle and there is a rich deposit of petroleum and natural gas, which arouses the strong will of eight surrounding countries (G 8) to participate in the management of the Arctic affairs. Russia has changed its attitude in order to promote the development of the northern areas and the external transport of the polar energy and wished more ships to enter and use NSR by revising its management regulations for ships sailing in the Northern Sea. But geopolitics is characterized in uncertainty and complicatedness and in face of the enormous economic profit, complicated international relationship and geopolitics, whether Russia will change its present attitude and set up higher entrance level in NSR, it awaits observation.

\subsubsection{Problems of Safe Navigation}

On account of the severe weather conditions in polar areas, the safety of the ships sailing in NSR is not to be neglected. Presently, the level of safety in the Arctic Northeast Route, especially NSR is still low, in that, the navigational guarantee system is imperfect; navigational marks and equipment are inadequate, far less to satisfy the need of safety; the infrastructural facilities in the ports along NSR are weak, with low provision and maintenance abilities; the search and rescue abilities in the whole area of the Northern Sea are weak and ships will not hopefully be able to find any salvage within short time limit in case of accident in the area; the Russian sea charts necessary for the transit in NSR are only available through agents, not only high in price but also rare in availability; other information concerning NSR is only to be acquired through Admiralty publications, not detailed, and although there are nautical publications in Russia, but in Russian, hard for understanding; Russia can provide services in meteorology, ice condition and navigation for ships transiting NSR, but its systematicness, timeliness and accuracy are not satisfactory; in high latitude areas, high frequency communication is blocked and sometimes not available; in the high latitude areas in the North Pole, some navigational instruments bear deviations and even unworkable. The foregoing problems bring forth major threats to the safety of navigation for ships transiting the Arctic Northeast Route.

2.1.4 The Present Ship Technical Conditions Cannot Satisfy the Needs for Sailing in Polar Waters

In accordance with the acquired IMO "Polar Code" and the "Requirement for the Design, Equipment and Supplies of Vessels Navigating the Northern Sea Route" of Russia, ships sailing in the Arctic Northeast Route shall have the corresponding ice classes, with anti-freezing abilities. But few Chinese merchant ships have the ice classes and even those ships that have the ice classes are low level and they will not satisfy the needs for sailing in polar waters. The lack of the seaworthy ships for sailing in ice areas may make an embarrassment after the full opening of the Arctic Northeast Route.

2.1.5 Lack of Experienced Seafarers for Sailing in Polar Waters

On ships sailing in the Arctic Northeast Route, except for the requirement that the masters shall have a sailing experience of at least 3 months and more for sailing in polar waters, it is also required that the seafarers shall have special training and have 
command of the knowledge and skills of identification of snow and ice, survival in cold weather, using the survival equipment in low temperatures, safe evacuation in ice areas, ship maneuvering in ice areas, icebreaking and convoy in ice areas, etc. For ships entering the ice areas, its maneuver bears its own characteristics and requires the masters and deck officers to have the corresponding experience, knowledge and skills and sound psychological qualifications. Presently, China lacks seafarers with the necessary experience, knowledge and skills for sailing in polar waters. The special training is of extreme necessity and it will be hard to find suitable seafarers if we do not start right now.

\subsection{Actions to Be Taken by the Shipping Industries for Developing and Exploiting the Arctic Northeast Route}

The full opening of the Arctic Northeast Route is not far away and Chinese shipping industries need to put their eyes on the route and take active actions to make various preparations for the adequate exploitation of the route. The actions include:

\subsubsection{Rendering Prospective Studies on the} Commercial Use of the Arctic Northeast Route

The contents should include, the legislations and practical affairs concerning the Arctic Northeast Route; the natural conditions, meteorology and ice conditions and geopolitics of the Arctic Northeast Route; the attitude and relevant policies concerning Chinese ships entering and using the Arctic Northeast Route; the navigational risks in sailing in the Arctic Northeast Route; the safety guarantee for ships sailing in the Arctic Northeast Route; the source of cargo, flow and amount using the Arctic Northeast Route for transportation; the commercial value and transportation costs of the Arctic Northeast Route; the requirements of environmental protection and practical affairs of the Arctic Northeast Route, etc. As far as the practical situations of the cargo, ports and natural situations along the Arctic Northeast Route, recent considerations are preferred in the external transportation of the local mineral products of petroleum and natural gas and the transit of some cargo in bulk form. In future, if the snow and ice are melted faster, the navigable time of the whole year can be extended, container liners are expectable. On account of the difficulties and problems to be solved in the commercial transportation via the Arctic Northeast Route, those shipping industries intending to open up commercial transportation in the Arctic Northeast Route should start their studies on the exploitation of the Arctic Northeast Route right now.

2.2.2 Participation in the Construction of the Ports in Russian Northern Sea

In order to reduce the risks for ships transiting the Arctic Northeast Route, provide the necessary safety guarantee for the ships and for the convenience of the cargo distribution along the route, the shipping industries are suggested to participate with Russia in the construction of the ports in Russian Northern Sea. Large state-owned shipping industries can even thins of investment there into the construction of the ship supply and maintenance and logistics centers in suitable places on the two ends of the Arctic Northeast Route.

2.2.3 Building Ships to Suit the Navigation in the Arctic Northeast Route

It is necessary to take careful studies of the "Polar Code," learn the requirements for ships sailing in polar waters and learn the building specifications for ships with various ice classes. Large state-owned shipping industries should put their eyes on the international shipping markets and take the lead in building a self-owned fleet navigable in the polar waters when conditions are mature to make preparations for the participation in the development of polar petroleum, gas and sea bottom resources and exploitation of the Arctic Northeast Route for commercial transportation.

2.2.4 Training of Seafarers Experienced in Sailing in Polar Waters as Soon as Applicable

Navigation in polar waters bears high requirements 
on the experience of sailing in polar waters, knowledge, skills and qualifications. Those shipping industries interested in the commercial transportation in polar waters should start right now to train and store the polar seafarers and conduct special training to the seafarers to provide service on ships sailing in polar waters in accordance with the IMO Resolution A.1024 (26) and amendments to the STCW Convention concerning the mandatory training and certification of polar seafarers to come into force on January 1st, 2018, and create opportunities to send them onboard ships sailing in polar waters to promote their experience, knowledge and skills for polar navigation and accumulate their experience in polar navigation.

2.2.5 Studying the Techniques for Navigation and Maneuver in Polar Waters

Those shipping industries interested in the commercial transportation in the Arctic Northeast Route should conduct the necessary techniques for navigation and maneuver in polar waters. A shipping industry with little knowledge in the navigation and maneuver in polar waters is unable to organize, command and manage the commercial transportation in the Arctic Northeast Route.

2.2.6 Establish the Safety Guarantee Mechanism for Sailing in Polar Waters

It is necessary, via the revision to the company safety management system, to establish a safety management system capable of effective management of the ships sailing in polar waters and provide safety guarantee for the ships sailing in polar waters through the operation of the system.

\section{Conclusion}

The purpose of implementing the "Seapard Project" is to find out a safe channel in connecting middle Europe for China and aims at the research and practice in opening up a channel to middle and west Europe, which is safer, faster, low cost, low energy consumption and less pollution. The success of the maiden voyage of MV "Yong Sheng" not only discovered a new route for the shipping industries of China, but also accumulated the experience in navigation in polar waters, ship maneuver and management and stored a group of seafarers with the experience, knowledge and skills in sailing in polar waters.

The success of the maiden voyage of MV "Yong Sheng" has collected large amount of data and materials for the better exploitation of the Arctic Northeast Route for Chinese merchant ships. This article renders initial sorting of the data and materials and it is the authors' wish to provide assistance for the shipping industries interested in opening up the Arctic Northeast Route.

\section{Acknowledgements}

Funded by the research project of "Training of Seafarers Sailing in Polar Waters", Shandong Province, China. (Project No.: J16WG47)

\section{References}

[1] Perez-Romero, J., Sallent, O., Agusti, R., and Diaz-Guerra, M. A. 2005. Radio Resource Management Strategies in UMTS. NY, USA: John Wiley \& Sons.

[2] Patachaianand, R., and Sandrasegaran, K. 2007. "Consecutive Transmit Power Control Ratio Aided Adaptive Power Control for UMTS.” Electronics Letters 43 (5): 55-6. 